\title{
Hypertension and determinants of blood pressure with special reference to socioeconomic status in a rural south Indian community
}

\author{
Ericus C A M Gilberts, Marinus J C W J Arnold, Diederick E Grobbee
}

\begin{abstract}
Objectives - The objective of the study was to establish the prevalence of hypertension and to assess determinants of blood pressure with special reference to socioeconomic status in a rural south Indian community.

Design - This was a door to door, cross sectional survey.

Setting - A rural south Indian community, KV Kuppam panchayat, North Arcot District, Tamil Nadu.

Subjects - The area has a total population of 3500 people. Those aged over 20 years who were available at the time of measurement were asked to participate (mean age 39.5 years). This convenience sample totalled 1027 (456 men, 571 women). Out of 697 families, 487 were visited; 15 people refused to participate. Measurements and main results - The following potential determinants of blood pressure were assessed: age, body weight, pulse rate, salt intake, meat intake, and socioeconomic class. The prevalence of hypertension was $12 \cdot 5 \%$. Using multiple linear regression analysis, the most important positive determinants of high blood pressure seemed to be age, body weight, and pulse rate. Salt and meat intake were not significantly associated with hypertension. The prevalence of hypertension in the highest socioeconomic group $(22 \cdot 5 \%)$ was more than twice that in the lowest socioeconomic group $(8 \cdot 8 \%)$. When adjusted for body weight, the mean (SEM) difference in systolic blood pressure between the highest and lowest socioeconomic classes was $5.83 \mathrm{mmHg}(1.63)$. Conclusion - Hypertension is not yet as important a health problem in rural southern India as it is in westernised societies. Those particularly at risk of hypertension, however, are the elderly and overweight people of high socioeconomic class.
\end{abstract}

\section{( $\mathcal{J}$ Epidemiol Community Health 1994;48:258-261)}

Atherosclerosis is the most important cause of death in western countries. In general, this does not apply in developing countries ${ }^{1}$ but there are indications that the incidence of cardiovascular morbidity and mortality is increasing in these countries. ${ }^{2-4}$ Moreover, migration studies have pointed out a high susceptibility for atherosclerosis in people of
Indian origin who live overseas. ${ }^{5-11}$ The disease prevalence in Indian immigrants often exceeds that of the host country. ${ }^{12}$ Since hypertension is one of the most important established risk factors for atherosclerosis, information about high blood pressure and its determinants is becoming increasingly important for health services in India. Results from studies on hypertension in communities in northern India indicate a prevalence ranging from $0.4 \%$ in rural areas up to $15 \%$ in towns. ${ }^{13-18}$ There are, however, no data about the prevalence of hypertension in south India. Since two studies have suggested that the prevalence of coronary heart disease is greater in south than in north India, ${ }^{819}$ we were interested to investigate hypertension in south India. We studied its prevalence and some potentially important and modifiable determinants of hypertension in a rural area of south India. Emphasis was placed on the association between blood pressure and socioeconomic status.

\section{Methods}

The study was carried out in a rural area known as KV Kuppam panchayat. Mainly because of agricultural activities, the area is economically self sufficient. This panchayat was chosen because sufficient numbers of subjects belonging to different socioeconomic groups were available. Out of a total population of 3500 people, all those over 20 years and available at the time of measurement were asked to participate. The study population therefore comprised 1027 subjects, 456 men and 571 women. The people were interviewed in their homes. The whole village was visited, except for two streets in which mostly moderately rich people lived. Out of 697 families, 487 $(71 \%)$ were reached in the survey. The remaining families were either absent or lived in the two streets that were not included. Not all members of the families were present at the time of measurement. Of the people available, only a few (15) refused to participate.

The blood pressure measurements were performed by two observers (EG and MA). During the whole study the same two sphygmomanometers were used. With the subject seated, the right arm was used to measure blood pressure and pulse rate. Blood pressure was determined twice within a five minute period. Whenever obesity was apparent a large arm cuff was used. The blood pressure was read to the nearest $2 \mathrm{mmHg}$. The mean systolic and diastolic blood pressure was calculated from the two readings. 
Table 1 Indications of socioeconomic class used in the present study

\begin{tabular}{llll}
\hline & Rich & Moderately rich & Poor \\
\hline Land & $\geqslant 9$ acres & $\geqslant 2$ and $<9$ acres & $<2$ acres \\
Livestock & $>2$ cows & 1 or 2 cows & No cows \\
Roof & Terraced & Tiled & Thatched \\
Occupation & Large landowner & Official & Agricultural labourer \\
& Store owner & Schooled labourer & Unschooled factory \\
& Trader & Self-employed person & worker \\
& with limited income & Mason \\
Employees & 1 or more & None & None \\
\hline
\end{tabular}

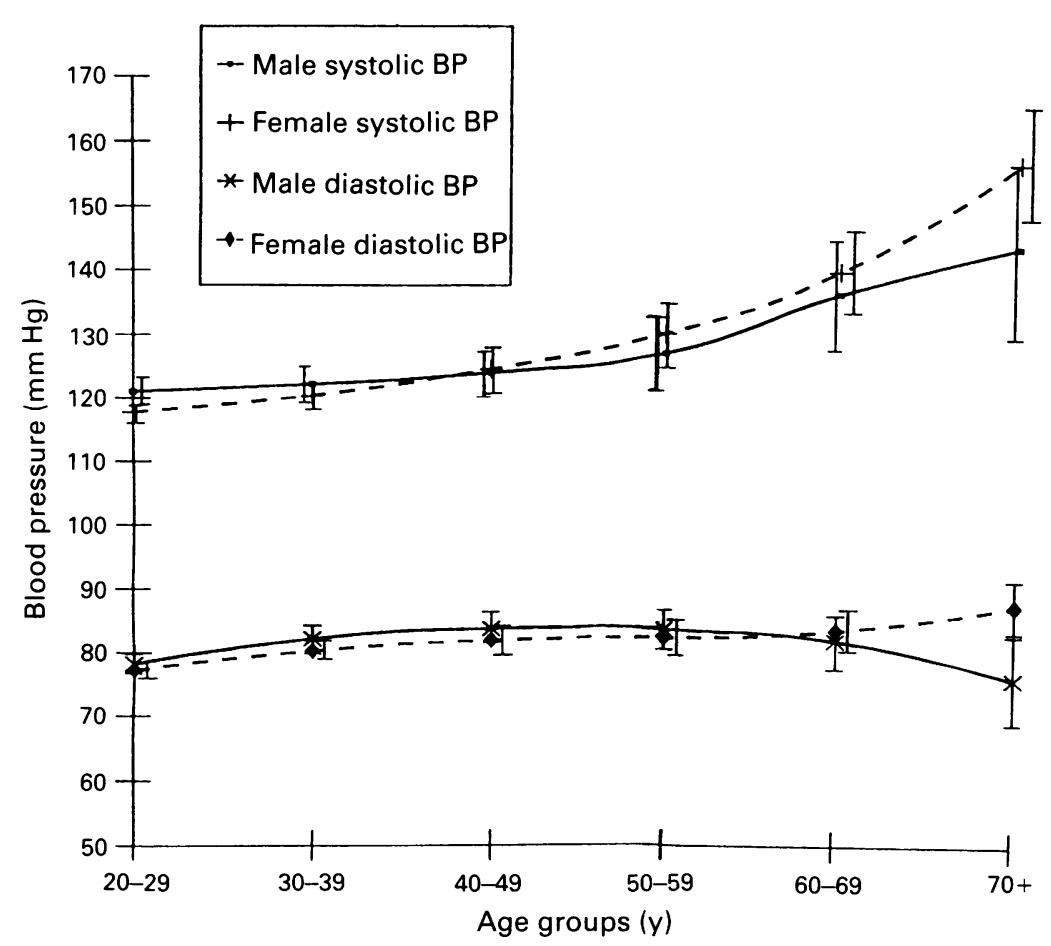

Figure 1 Mean systolic and diastolic blood pressures with $95 \%$ confidence intervals in relation to gender and age group.

WHO criteria were used to determine hypertension - that is a systolic blood pressure $\geq 160 \mathrm{mmHg}$ or diastolic blood pressure $\geq 95 \mathrm{mmHg}$, or both. ${ }^{20}$

The following determinants of hypertension were assessed: age, body weight, pulse rate, salt intake, meat intake, and socioeconomic status. Body weight was recorded with the subject standing on a weighing scale without support and with minimal clothing. Body height was not recorded; however, several studies have shown that body weight and body mass index are independent determinants of blood pressure. ${ }^{2122}$ Since these rural people prepare all their food themselves from the basic ingredients, the intake of salt could be estimated from that added during cooking. The natural salt content of food was not taken into account. Information on the amount of salt bought by each household in a month was sought (via a translator). This was subsequently divided according to the number of members in that household. The frequency of meat intake in a week was also determined and was used to estimate animal fat and protein consumption. The socioeconomic status was ascertained according to land and livestock ownership and the type of roof. Information was also obtained on occupation and number of employees in the household (table 1 ).

The statistical analysis was carried out by means of the SPSS/PC + package. Means and regression coefficients of the potential determinants of blood pressure were calculated for the different sexes and socioeconomic classes. In addition, the interaction effect between socioeconomic class and body weight was tested in covariance analyses. Social class was coded as two dummy variables (dropping the lower class category) and body weight was included as a cross product. The prevalence of hypertension in this study was compared with studies in western societies.

\section{Results}

Descriptive statistics for the study population by age decade are shown in table 2 . The overall prevalence of hypertension found in KV Kuppam panchayat was $12.5 \%$. The prevalence of hypertension and the mean blood pressure were greater in men than in women until the 5 th decade - the pattern was then reversed in the subsequent age groups (fig 1).

Crude regression coefficients showed a significant association of age, body weight, pulse rate, and socioeconomic class with both systolic and diastolic pressure. No significant association between gender, salt, and meat intake and blood pressure was observed (table 3).

Table 3 also shows that age, body weight, and pulse rate remained independently associated with both systolic and diastolic blood pressure after adjustment for differences in other variables. Socioeconomic status was still associated with systolic blood pressure while gender had only a weak association with diastolic blood pressure after adjustment.

Table 2 General characteristics of the population. Values are mean ( $95 \%$ confidence interval)

\begin{tabular}{|c|c|c|c|c|c|c|c|c|}
\hline $\begin{array}{l}\text { Age decade } \\
(y)\end{array}$ & $\begin{array}{l}\text { Total } \\
\text { no }\end{array}$ & $\begin{array}{l}\text { Male } \\
\text { no }\end{array}$ & $\begin{array}{l}\text { Female } \\
\text { no }\end{array}$ & $\begin{array}{l}\text { Systolic BP } \\
(\mathrm{mm} \mathrm{Hg})\end{array}$ & $\begin{array}{l}\text { Diastolic } B P \\
(\mathrm{~mm} \mathrm{Hg})\end{array}$ & $\begin{array}{l}\text { Hypertension } \\
(\%)\end{array}$ & $\begin{array}{l}\text { Body weight } \\
(\mathrm{kg})\end{array}$ & $\begin{array}{l}\text { Pulse rate } \\
\text { (beats min) }\end{array}$ \\
\hline $20-29$ & 349 & 159 & 190 & \multirow{6}{*}{$\begin{array}{l}119 \cdot 3 \\
(118 \cdot 0,120 \cdot 5) \\
120 \cdot 9 \\
(119 \cdot 7,122 \cdot 6) \\
123 \cdot 9 \\
(121 \cdot 4,126 \cdot 4) \\
128 \cdot 4 \\
(124 \cdot 6,132 \cdot 1) \\
138 \cdot 0 \\
(133 \cdot 0,143 \cdot 0) \\
149 \cdot 3 \\
(141 \cdot 4,157 \cdot 2)\end{array}$} & \multirow{6}{*}{$\begin{array}{l}77 \cdot 7 \\
(76 \cdot 7,78 \cdot 7) \\
81 \cdot 1 \\
(80 \cdot 0,82 \cdot 3) \\
82 \cdot 8 \\
(81 \cdot 1,84 \cdot 5) \\
82 \cdot 4 \\
(80 \cdot 3,84 \cdot 4) \\
82 \cdot 5 \\
(80 \cdot 0,85 \cdot 0) \\
80 \cdot 9 \\
(76 \cdot 6,85 \cdot 1)\end{array}$} & $3 \cdot 7 \%$ & \multirow{6}{*}{$\begin{array}{l}49 \cdot 5 \\
(48 \cdot 5,50 \cdot 7) \\
52 \cdot 7 \\
(51 \cdot 3,54 \cdot 4) \\
53 \cdot 6 \\
(51 \cdot 7,55 \cdot 5) \\
51 \cdot 7 \\
(49 \cdot 6,53 \cdot 7) \\
49 \cdot 8 \\
(47 \cdot 2,52 \cdot 5) \\
48 \cdot 4 \\
(44 \cdot 4,52 \cdot 4)\end{array}$} & \multirow{6}{*}{$\begin{array}{l}82 \cdot 4 \\
(81 \cdot 0,83 \cdot 8) \\
83 \cdot 3 \\
(81 \cdot 7,84 \cdot 8) \\
83 \cdot 3 \\
(82 \cdot 2,85 \cdot 5) \\
83 \cdot 0 \\
(81 \cdot 0,85 \cdot 0) \\
83 \cdot 5 \\
(81 \cdot 0,86 \cdot 0) \\
87 \cdot 3 \\
(83 \cdot 4,91 \cdot 3)\end{array}$} \\
\hline 30-39 & 227 & 89 & 138 & & & $7 \cdot 9 \%$ & & \\
\hline $40-49$ & 172 & 89 & 83 & & & $17 \cdot 4 \%$ & & \\
\hline $50-59$ & 134 & 54 & 80 & & & $17 \cdot 2 \%$ & & \\
\hline $60-69$ & 93 & 37 & 56 & & & $26 \cdot 9 \%$ & & \\
\hline $70+$ & 51 & 27 & 24 & & & $37 \cdot 3 \%$ & & \\
\hline All ages & 1027 & 456 & 571 & $\begin{array}{l}124 \cdot 8 \\
(123 \cdot 6,125 \cdot 9)\end{array}$ & $\begin{array}{l}80 \cdot 5 \\
(78 \cdot 9,81 \cdot 2)\end{array}$ & $12.5 \%$ & $\begin{array}{l}51 \cdot 1 \\
(50 \cdot 5,51 \cdot 9)\end{array}$ & $\begin{array}{l}83 \cdot 2 \\
(82 \cdot 5,84 \cdot 0)\end{array}$ \\
\hline
\end{tabular}


Table 3 Crude and adjusted linear multiple regression coefficients of potential determinants. Values are mean (95\% confidence intervals)

\begin{tabular}{|c|c|c|c|c|}
\hline & \multicolumn{2}{|c|}{ Systolic blood pressure $(\mathrm{mm} \mathrm{Hg})$} & \multicolumn{2}{|c|}{ Diastolic blood pressure $(\mathrm{mm} \mathrm{Hg})$} \\
\hline & $\begin{array}{l}\text { Crude regression } \\
\text { coefficient }\end{array}$ & $\begin{array}{l}\text { Adjusted regression } \\
\text { coefficient }\end{array}$ & $\begin{array}{l}\text { Crude regression } \\
\text { coefficient }\end{array}$ & $\begin{array}{l}\text { Adjusted regression } \\
\text { coefficient }\end{array}$ \\
\hline Age (y) & $0.47(0.40,0.54)$ & $0.46(0.40,0.52)$ & $0 \cdot 10(0 \cdot 06,0 \cdot 14)$ & $0 \cdot 10(0 \cdot 06,0 \cdot 14)$ \\
\hline Body weight (kg) & $0.41(0 \cdot 32,0 \cdot 50)$ & $0.36(0 \cdot 27,0 \cdot 45)$ & $0.32(0 \cdot 27,0 \cdot 37)$ & $0.35(0.30,0.40)$ \\
\hline Pulse rate (beats $/ \mathrm{min}$ ) & $0.27(0 \cdot 18,0 \cdot 36)$ & $0.25(0.17,0.33)$ & $0 \cdot 12(0.07,0 \cdot 17)$ & $0.11(0 \cdot 06,0 \cdot 16)$ \\
\hline Socioeconomic status & $4 \cdot 71(3 \cdot 24,6 \cdot 18)$ & $2 \cdot 15(0 \cdot 74,3 \cdot 56)$ & $2 \cdot 46(0 \cdot 60,3 \cdot 32)$ & - \\
\hline Salt & $-3.49(-11 \cdot 82,4 \cdot 84)$ & - & $-0.075(-4.94,4 \cdot 79)$ & - \\
\hline Meat & $-1 \cdot 22(-2 \cdot 28,-0 \cdot 16)$ & - & $0.13(-0.48,0.74)$ & - \\
\hline Sex & $-0.35(-2.62,1.92)$ & - & $-0.56(-1.89,0.77)$ & $1.59(0.29,2 \cdot 89)$ \\
\hline
\end{tabular}

Table 4 Mean ( $95 \%$ confidence interval) of blood pressure and potential determinants by socioeconomic class and sex

\begin{tabular}{|c|c|c|c|c|}
\hline & Rich & Moderately rich & Poor & \multirow[t]{2}{*}{ p value } \\
\hline & $\begin{array}{l}(n=213, \\
\text { hypertension } 22.5 \%)\end{array}$ & $\begin{array}{l}(n=407, \\
\text { hypertension } 10 \cdot 8 \%)\end{array}$ & $\begin{array}{l}(n=407, \\
\text { hypertension } 8.8 \%)\end{array}$ & \\
\hline \multicolumn{5}{|l|}{ Men: } \\
\hline $\begin{array}{l}\text { Systolic blood pressure }(\mathrm{mm} \mathrm{Hg}) \\
\text { Diastolic blood pressure }(\mathrm{mm} \mathrm{Hg}) \\
\text { Age }(\mathrm{y}) \\
\text { Body weight }(\mathrm{kg}) \\
\text { Pulse rate }(\text { beats } / \mathrm{min}) \\
\text { Salt intake }(\mathrm{kg} / \mathrm{mth}) \\
\text { Meat intake (frequency } / \mathrm{wk})\end{array}$ & $\begin{aligned} 132 \cdot 4 & (128 \cdot 4,136 \cdot 4) \\
84 \cdot 5 & (82 \cdot 5,86 \cdot 5) \\
40 \cdot 3 & (37 \cdot 0,43 \cdot 6) \\
62 \cdot 8 & (60 \cdot 3,65 \cdot 2) \\
81 \cdot 7 & (79 \cdot 2,84 \cdot 2) \\
0 \cdot 37 & (0 \cdot 27,0 \cdot 66) \\
0 \cdot 43 & (0 \cdot 30,0 \cdot 56)\end{aligned}$ & $\begin{aligned} 124 \cdot 6 & (122 \cdot 0,127 \cdot 2) \\
81 \cdot 2 & (79 \cdot 6,82 \cdot 8) \\
40 \cdot 2 & (38 \cdot 0,42 \cdot 4) \\
56 \cdot 9 & (55 \cdot 2,58 \cdot 5) \\
80 \cdot 1 & (78 \cdot 4,81 \cdot 8) \\
0 \cdot 39 & (0 \cdot 37,0 \cdot 41) \\
0 \cdot 91 & (0 \cdot 74,1 \cdot 09)\end{aligned}$ & $\begin{aligned} 121 \cdot 0 & (118 \cdot 2,123 \cdot 7) \\
78 \cdot 3 & (76 \cdot 2,80 \cdot 0) \\
39 \cdot 2 & (36 \cdot 9,41 \cdot 5) \\
49 \cdot 3 & (48 \cdot 0,50 \cdot 6) \\
81 \cdot 6 & (79 \cdot 7,83 \cdot 5) \\
0 \cdot 36 & (0 \cdot 32,0 \cdot 63) \\
0 \cdot 87 & (0 \cdot 67,1 \cdot 06)\end{aligned}$ & $\begin{array}{l}\mathrm{p}<0.001 \\
\mathrm{p}<0.001 \\
\mathrm{p}<0.554 \\
\mathrm{p}<0.001 \\
\mathrm{p}<0.959 \\
\mathrm{p}<0.776 \\
\mathrm{p}<0.008\end{array}$ \\
\hline \multicolumn{5}{|l|}{ Women: } \\
\hline $\begin{array}{l}\text { Systolic blood pressure }(\mathrm{mm} \mathrm{Hg}) \\
\text { Diastolic blood pressure }(\mathrm{mm} \mathrm{Hg}) \\
\text { Age }(\mathrm{y}) \\
\text { Body weight }(\mathrm{kg}) \\
\text { Pulse rate }(\mathrm{beats} / \mathrm{min}) \\
\text { Salt intake }(\mathrm{kg} / \mathrm{mth}) \\
\text { Meat intake (frequency } / \mathrm{wk})\end{array}$ & $\begin{aligned} 131 \cdot 7 & (128 \cdot 0,135 \cdot 5) \\
82 \cdot 8 & (80 \cdot 7,84 \cdot 4) \\
41 \cdot 3 & (38 \cdot 3,44 \cdot 3) \\
54 \cdot 7 & (52 \cdot 4,57 \cdot 0) \\
86 \cdot 6 & (84 \cdot 5,88 \cdot 6) \\
0 \cdot 38 & (0 \cdot 35,0 \cdot 41) \\
0 \cdot 45 & (0 \cdot 33,0 \cdot 57)\end{aligned}$ & $\begin{aligned} 123 \cdot 9 & (121 \cdot 6,126 \cdot 1) \\
80 \cdot 7 & (79 \cdot 4,81 \cdot 9) \\
37 \cdot 0 & (36 \cdot 0,39 \cdot 7) \\
49 \cdot 3 & (47 \cdot 9,50 \cdot 6) \\
84 \cdot 3 & (82 \cdot 5,86 \cdot 0) \\
0 \cdot 38 & (0 \cdot 37,0 \cdot 40) \\
0 \cdot 90 & (0 \cdot 77,1 \cdot 04)\end{aligned}$ & $\begin{aligned} 122 \cdot 0 & (119 \cdot 6,124 \cdot 2) \\
78 \cdot 7 & (77 \cdot 4,79 \cdot 9) \\
39 \cdot 6 & (37 \cdot 5,41 \cdot 6) \\
43 \cdot 5 & (42 \cdot 5,44 \cdot 5) \\
84 \cdot 9 & (83 \cdot 5,86 \cdot 4) \\
0 \cdot 38 & (0 \cdot 37,0 \cdot 40) \\
0 \cdot 76 & (0 \cdot 61,0 \cdot 91)\end{aligned}$ & $\begin{array}{l}p<0.001 \\
p<0.001 \\
p<0.576 \\
p<0.001 \\
p<0.441 \\
p<0.989 \\
p<0.061\end{array}$ \\
\hline
\end{tabular}

The prevalence of hypertension was significantly $(p<0.001)$ higher in rich people $(22.5 \%)$ than poor $(8.8 \%)$. As is shown in table 4 , the mean systolic and diastolic blood pressures differed considerably between these groups. Table 4 also indicates that body weight was to be the only measured determinant of blood pressure significantly different between the socioeconomic groups. Correction for body weight resulted in a reduction of the difference in systolic blood pressure between the highest and lowest socioeconomic groups to $5.83(1.63) \mathrm{mmHg}$.

Additional analysis, including an indicator for vegetarians and non-vegetarians, did not show a significant difference in systolic or diastolic blood pressure.

\section{Discussion}

Compared with other population studies in
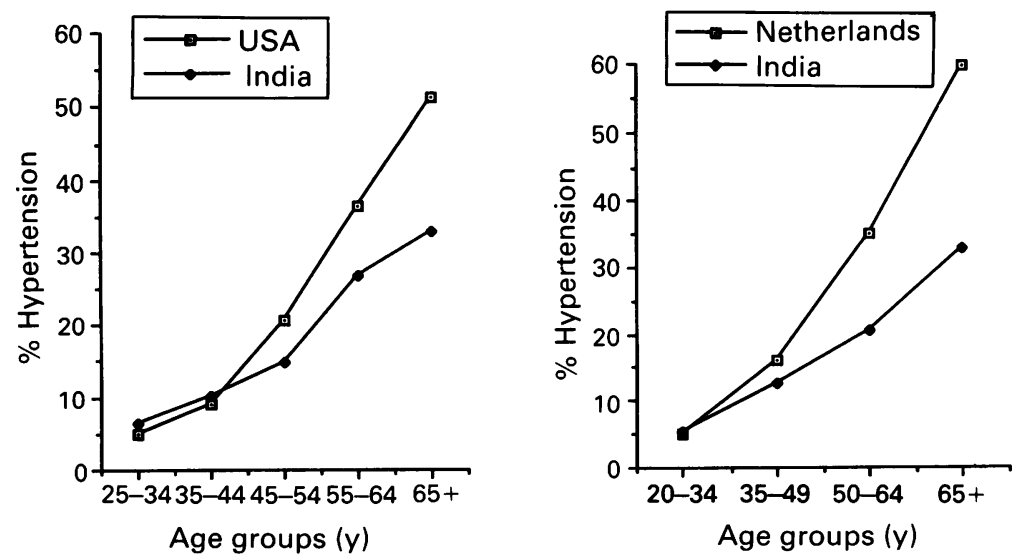

Figure 2 Prevalence rates of hypertension in relation to age group in the present study and in studies performed in the US $A^{29}$ and The Netherlands. north India, the prevalence of hypertension in this south Indian community is considerably higher. The prevalence of hypertension found in this study was $12.5 \%$, and that reported from northern rural communities is about $4 \% .{ }^{13-1517}$ Even in many urbanised areas, the prevalence of hypertension seems to be lower in north India. ${ }^{1316}$

Compared with similar and age standardised studies in western countries, the prevalence of hypertension found in this study population is considerably lower. This accounts for urban as well as for rural areas. ${ }^{23-28}$ This difference can be partly explained by the relatively larger number of elderly people in the total adult population of the western countries. When we look at the prevalence of hypertension in different age groups in white Americans and suburban Dutch people and compare these data with ours, it is evident that the prevalence of hypertension is about the same in the younger age groups. However, in western societies elderly people are more likely to have hypertension (fig 2). ${ }^{2329}$ This may be due to less health care and higher mortality from noncardiovascular diseases in India which means survival of the fittest, thus eliminating potential hypertensive subjects among the elderly. When medical attention improves and life expectancy rises in India, hypertension will probably become a more prominent problem.

Our study, as well as many others, shows a difference in the increase in blood pressure with age between men and women. ${ }^{1317212329} 30-33$ One explanation for the steeper curve in blood pressure with advancing age in women may be the gain in body weight or other changes after the menopause. ${ }^{33}$

In this study, hypertension was observed more than twice as often in rich than in poor people. The risk of developing atherosclerosis 
in the first group is, therefore, considerably raised. With the further improvement in the Indian economy, the percentage of people in the high socioeconomic group will inevitably rise, which may lead to a higher prevalence of hypertension in the Indian population. An important feature in preventing this trend can be a reduction of body weight and prevention of obesity in the higher socioeconomic classes. Several studies have clearly shown a positive effect of weight reduction on the blood pressure level. ${ }^{34-40}$ As this study has indicated, the blood pressure differences between high and low socioeconomic class were considerably reduced after statistical adjustment for body weight. Unfortunately, being obese is still a deeply rooted status symbol in these rural areas and it might be a challenge for the local health services to try to change this attitude.

It has been determined that there are populations in which salt intake correlates well with hypertension, for example American blacks. ${ }^{41}$ It may be important to obtain information on this in these Indian population groups. Further studies may assess whether a reduction in salt intake results in a fall in the prevalence of hypertension in south Indian populations.

From this study we conclude that the prevalence of hypertension in this south Indian community increases with age, body weight, heart rate, and socioeconomic status. On the whole it is not yet as important a health problem as it is in western societies. The prevalence of hypertension is, however, likely to increase when improvement in medical care increases life expectancy and economic changes improve the socioeconomic standing. With respect to the latter, obesity and increases in body weight appear to be important mediators of an increase in blood pressure levels.

We wish to thank Dr Rajaratnan Abel for his advice and support and the people of KV Kuppam for their cooperation and hospitality.

1 World Health Organization. Statistics annual. WHO Geneva, 1990

2 Vaughan JP. A review of cardiovascular diseases in develop ing countries. Ann Trop Med Parasitol 1978;72:101-9.

3 Hatano S. Problems of hypertension in the Asian-Pacific area. In: Kesteloot H. Epidemiology of arterial blood pressure. The Hague: Martinus Nijhoff, 1980:265-96.

4 Sarvotham SG, Berry JN. Prevalence of coronary hear disease in an urban population in northern India. Circulation 1968;37:939-53.

5 Tunstall-Pedoe H, Clayton D, Morris JN, Brigden W, Mcdonald L. Coronary heart attacks in east London. Lancet 1975; ii:833-8.

6 Shaper AG, Jones KW. Serum cholesterol, diet, and coronary heart disease in Africans and Asians in Uganda Lancet 1959;ii:534-7.

7 Walker ARP. The epidemiology of ischaemic heart disease in the different ethnic populations in Johannesburg. $S$ Afr Med f 1980;57:748-52.

8 Balarajan R, Bulusu L, Adelstein AM, Shukla V. Patterns of mortality among migrants to England and Wales from of mortality among migrants to England and Wa

9 Anonymous. Coronary heart disease in Indians overseas. Editorial. Lancet 1986;i:1307-8.

10 Mckeique PM, Miller GJ, Marmot MG. Coronary heart disease in South Asians overseas: a review. $\mathcal{f}$ Clin Epidemiol $1989 ; 42 \cdot 597-609$

11 Hughes K, Lun KC, Yeo PPB. Cardiovascular diseases in Chinese, Malays, and Indians in Singapore. I. Differences in mortality. $\mathcal{f}$ Epidemiol Community Health 1990;44:24-8.
12 Miller GJ, Beckles GLA, Alexis SD, Byam NTA, Price SGL. Serum lipoproteins and susceptibility of men of Indian descent to coronary heart disease.
Survey, Trinidad. Lancet 1982;ii:200-3.

13 Gupta SP, Siwach SB. Epidemiology of hypertension in a north Indian population. Based on rural-urban community surveys. Fpn Heart $\mathcal{F}$ 1984;25:65-73.

14 Sharma BK, Arora OP, Bansal BL, Sagar S, Khurana SK. Hypertension among the industrial workers and professional classes in Ludhiana, Punjab. Indian Heart $\mathcal{f}$ 1985;37:380-5.

15 Verma BL, Srivastava RN. Hypertension in Indian rural adults. Int $\mathcal{F}$ Epidemiol 1983;12:374-5.

16 Seedat YK. Hypertension and ischaemic heart disease in Indian people living in South Africa and in India. $S$ Afr Med f 1982;61:965-7.

17 Mukheriee BN, Byard PJ, Bhattacharya SK, Rao DC Blood pressure in a rural west Bengal fishing community: Blood pressure in a rural west Bengal fishing comm

18 Mir MA, Mir F, Khosla T, Newcombe R. The relationship of salt intake and arterial blood pressure in salted-tea drinking Kashmiris. Int $\mathcal{f}$ Cardiol 1986;13:279-88.

19 Malhotra SL. Epidemiology of ischaemic heart disease in India with special reference to causation. Br Heart $\mathcal{f}$ 1967;29:895-905.

20 World Health Organisation. Arterial hypertension. Geneva: WHO, 1978. WHO Technical Report Service no 628

21 Srivastava RN, Verma BL, Arun Kumar, Srivastava JP. The influence of some correlates of blood pressure on its distribution in an Indian rural community. 7 Epidemiol Community Health 1973;33:279-85.

22 Rao PSS, Inbaraj SG, Subramaniam VR. Blood pressure measures among women in South India. $\mathcal{F}$ Epidemiol Community Health 1984;38:49-53.

23 Hofman A, Valkenburg HA. Een epidemiologisch onderzok naar risicoindicatoren voor hart en vaatziekten (EPOZ). Ned Tijdschr Geneeskd 1980;124:189-95.

24 Rose GA. Hypertension in the community. In: Birkenhäger WH, Reid JL. Handbook of hypertension. Vol 6: Epidemi ology of hypertension. Amsterdam: Elsevier, 1985:1-14.

25 Gutzwiller F. Issues in health education: epidemiology and prevention of hypertension in Switzerland. Prev Med 1985;14:532-40.

26 O'Conner PJ, Wagner EH, Strogatz DS. Hypertension control in a rural community. An assessment of community-oriented primary care. F Fam Pract 1990;30:4204.

27 Wagner EH, Slome C, Carroll CL, et al. Hypertension control in a rural biracial community: successes and failures of primary care. Am $\mathcal{F}$ Public Health 1980;70:4855.

28 Heyden S, Durham NC, Walkel L, et al. Decrease of serum cholesterol level and blood pressure in the community. Seven to nine years of observation in the Evans County Seven to nine years of observation in the

29 Cornoni-Huntley J, LaCroix AZ, Havlik RJ. Race and sex differentials in the impact of hypertension in the United States. The National Health and Nutrition Examination Survey I. Epidemiologic follow up study. Arch Intern Med 1989;149:780-8.

30 Kannel WB. Host and environmental determinants of hypertension. Perspective from the Framingham Study. In Kesteloot H. Epidemiology of arterial blood pressure. The Hague: Martinus Nijhoff, 1980:265-96.

31 Blood pressure levels in persons 18-74 years of age in 1976-80. Data from National Health Survey Series II. No 234. Washington US Department of Health and Human Services, DHHS publication (PHS) 86-168, July 1986.

32 Rao RS. Blood pressure levels of Rellis (India) with special reference to variations with age. Hum Hered 1983;33:28790 .

33 Hovell MF. The experimental evidence for weight-loss treatment of essential hypertension: a critical review. $A m$ f Public Health 1982;72:359-68.

34 Grobbee DE, van Hemert AM, Vandenbroucke JP, Hof man A, Valkenburg HA. Importance of body weight in determining rise and level of blood pressure in postmenopausal women. 7 Hyperten 1988;6(Suppl):S614-6.

35 Final report of the Subcommittee on Nonpharmacologica Therapy of the 1984 Joint National Committee on Detection, Evaluation, and Treatment of High Blood Pressure. Nonpharmacological approaches to the control of high blood pressure. Hypertension 1986;8:444-67.

36 Schotte DE, Stunkard AJ. The effects of weight reduction on blood pressure in 301 obese patients. Arch Intern Med 1990;150:1701-4

37 Heyden S, Schneider KA. Obesity and hypertension: epidemiological aspects of the relationship. $\mathcal{F}$ Hum Hypertens 1990;4:431-5.

38 Singh RB, Rastogi SS, Singh DS, Mehta PJ. Effect of obesity and weight reduction in hypertension. Acta Cardiol 1990;45:45-56.

39 Langford HG, Blaufox D, Oberman A, et al. Dietary therapy slows the return of hypertension after stopping prolonged medication. $\mathcal{f} A M A$ 1985;253:657-64.

40 Chockalingam A Abbott D, Bass M, et al. Recommendations of the Canadian consensus conference on nonpharmacological approaches to the management of high blood pressure, Mar 21-23, 1989, Halifax, Nova Scotia. Can Med Assoc F 1990;142:1397-409.

41 Weinberger MH. Hypertension in blacks. Should it be treated differently? Cardiol Rev 1993;1:35-41. 